\title{
An investigation on the physical, mechanical and thermal properties of dune sand mortars lightened by expanded polystyrene beads (EPS)
}

OUIDED HERIHIRI - Department of Civil Engineering, University of Medea 26000, Algeria

- Civil Engineering Research Laboratory, University of Biskra 07000, Algeria

Abdelhamid GUETTALA - Civil Engineering Research Laboratory, University of Biskra 07000, Algeria

Benchaa BENABED - Civil Engineering Research Laboratory (LRGC),

University of Laghouat 03000, Algeria - b.benchaa@lagh-univ.dz

Érkezett: 2020. 04. 25. " Received: 25. 04. 2020. " https://doi.org/10.14382/epitoanyag-jsbcm.2021.6

Abdelhamid GUETTALA

Professor at the Department of Civil Engineering University of Biskra, Algeria. His research interests include, concrete technology, reuse of local materials.

Benchaa BENABED

Professor at the Department of Civil Engineering University of Laghouat, Algeria. His research interests include self-compacting concrete technology, reuse of local materials, rheology and durability of cement-based materials.

\begin{abstract}
As the idea of sustainable development has been involved in all fields including construction and civil engineering, a huge amount of researches has focused on reducing energy use and protecting the environment, while at the same time ensuring the comfort of inhabitant. Taking on this viewpoint, the current work focuses on replacing natural materials with recycled and synthetic materials, to produce a new eco-material that satisfies the binary concept; minimizing cost and constructing light elements with complex geometry that promotes architectural innovation. The present work aims to mix design and study a mortar based on mixture of fine siliceous dune sand and crushed limestone sand lightened by expanded polystyrene (EPS). Sand was substituted by EPS with percentages of 0, 5, 10, 15, 20, 25 and 100\%. The physical, mechanical and thermal properties of composite mortars were assessed according to the dry density, compressive strength, flexural strength, porosity, and conductivity. The obtained results show that, the use of EPS decreases the mechanical properties and the density of mortars. However, the thermal properties of mortars incorporating EPS were improved and meet the requirement for lightweight concrete constructions and insulation applications.

Keywords: EPS, dune sand, crushed sand, physic-mechanical properties, porosity, thermal properties

Kulcsszavak: EPS, dûne homok, zúzott homok, fizikai-mechanikai tulajdonságok, porozitás, hôtani tulajdonságok
\end{abstract}

\section{Introduction}

Concrete is the most widely used material in building construction despite its relatively high weight and limited thermal performance in which thermal conductivity ranges between 1.4 and 3.6 W/mK [1-3]. Lightweight concrete (LWC) offers a considerable advantage in terms of its unit weight which encourages its use in the construction industry where savings made in the weight of structures are a major factor [4]. Several researchers have exploited natural, artificial and recycled lightweight aggregates in order to enhance their importance in modern construction [5]. Expanded polystyrene (EPS) is one of the artificial lightweight aggregates that provide concrete lightening, and a wide range of density choices and is used in thermal insulation. The introduction of this material therefore contributes to the efficient management of solid waste while saving landfills, conserving natural resources and protecting the environment [6]. Herki et al [7] Examined the effect of using EPS waste and fly ash in concrete. The results showed that the compressive strength and ultrasonic velocity decreases with increasing amounts of EPS and fly ash in the concrete. FerrandizMas et al [8] investigated the effect of EPS on the thermal conductivity of lightweight mortars; the results showed that the increase in the percentage of EPS beads decreases the thermal conductivity, thus increasing the thermal insulation. Sayadi et al [9] found that the strength of lightweight concrete made with
EPS beads decreases as the amount of replacement EPS increases. Ali et al [10] have carried out some tests on concretes made of polyethylene balls; the results showed that regardless of the EPS balls content, the shrinkage of EPS concrete is greater than that of the control concrete. In the context of sustainable development, the Algerian Minister of Housing and Urban Planning has banned the exploitation of river and sea sand, as a justified way to preserve the environment; this is a major environmental challenge due to the increasing need for sand. In order to balance the country's need for sand in construction field and the preservation of the environment, researchers have started to introduce new ideas and innovative solutions for this complicated problem in one hand. On the other hand, the improved thermal performance of lightweight aggregate concrete is considered as the most appropriate, particularly in reducing the energy used in heating and air conditioning of buildings. Among the steps suggested by researchers is to use the quarry limestone crushed sand and to evaluate the economy of the aggregates sector. The approach alone, however, cannot satisfy the growing demand for development programs of construction projects. Nevertheless, the search for other alternatives to deal with the lack of materials especially the sand remains increasingly important. Recently, a shift in research towards new construction materials has taken place through the reuse of local materials for the construction of high-performance concrete from a mechanical and economic point of view as well as 
its durability. A local available dune sand which covers more than $60 \%$ of the Algerian territory is practically unexploited until now [11]. Many researches have been done on the use of dune sand in the field of construction in Algeria, due to the availability of this material in huge quantities especially in the southern zones [12-16]. The main objective of this work is to investigate the effect of EPS beads and plasticizer on the properties of mortar made with a mixture sand of dune and crushed sand, in order to meet the concern of preserving the natural resources, and enhance the thermal insulation of buildings. The physical, mechanical and thermal properties of mortar were evaluated according the dry density, compressive, flexural strength, porosity and thermal conductivity.

\section{Experimental program}

\subsection{Material}

\subsubsection{Cement}

The cement used in this work is a Portland Limestone Cement of type CPJ CEM/II which conforms to the standard EN 197-1:2000 [17]. Its specific density is $3.1 \mathrm{~g} / \mathrm{cm}^{3}$ and its Blaine specific surface area is $3100 \mathrm{~cm}^{2} / \mathrm{g}$.

\subsubsection{Sand}

As fine aggregates, a mixture of $44 \%$ of siliceous dune sand (DS) and 56\% limestone crushed sand (CS) were used. The physical properties and sieve analysis results of these sands are given in Table 1 and Fig. 1 respectively.

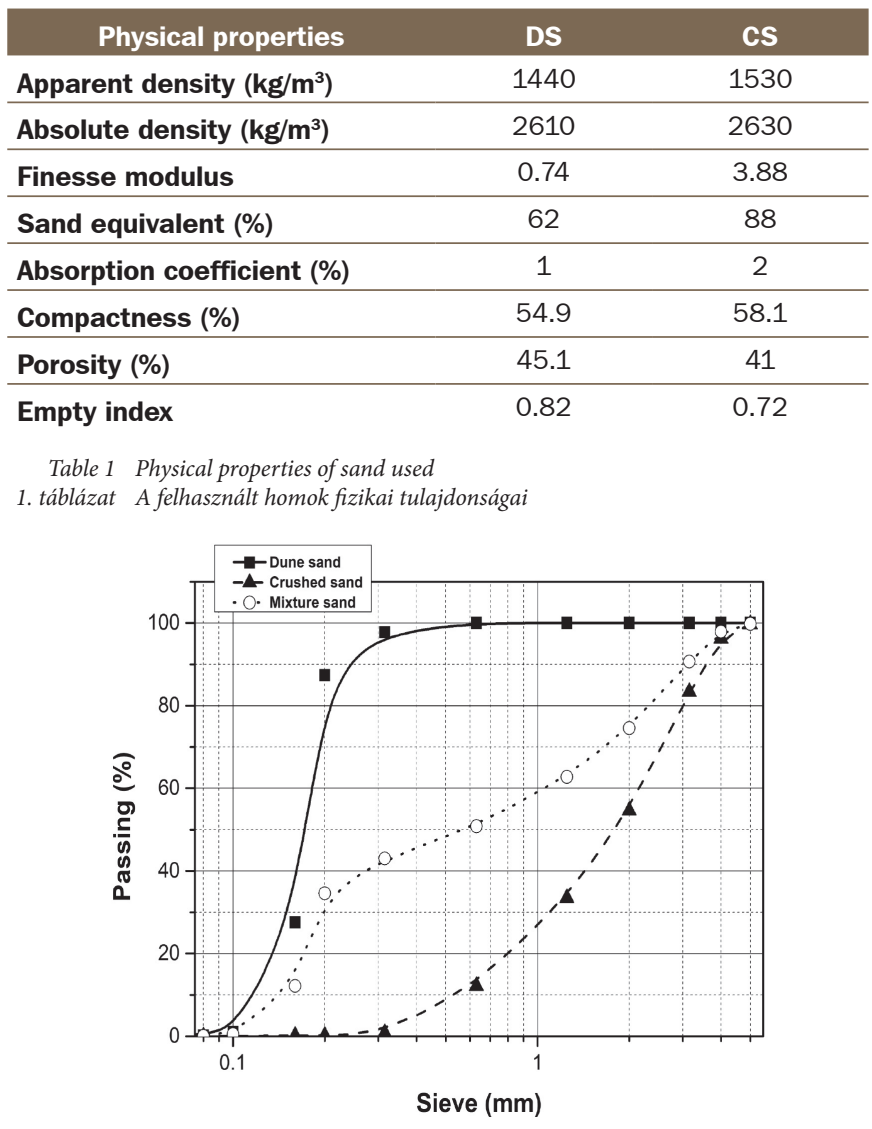

Fig. 1 Particle size distribution of sand used

1. ábra A felhasznált homok szemcseméret eloszlása

\subsubsection{Expanded polystyrene (EPS)}

The manufacture of polystyrene is obtained by polymerizing the basic product, which is styrene. The EPS balls with diameters ranging from 1.5 to $4 \mathrm{~mm}$ were used to substitute sand by percentage of $0,5,15,25,50,75$ and $100 \%$ to lighten the mortar. The properties of the EPS balls used are given in Table 2.

\begin{tabular}{lc}
\multicolumn{1}{c}{ Properties } & Value \\
\hline Particles' size $(\mathbf{m m})$ & $1.5-4$ \\
\hline Absolute density $\left(\mathbf{k g} / \mathbf{m}^{3}\right)$ & 28 \\
\hline Apparent density $\left(\mathbf{k g} / \mathbf{m}^{3}\right)$ & 18 \\
\hline Dry thermal conductivity (W/m.K) & 0.045 \\
Table 2 Properties of EPS & \\
2. táblázat EPS tulajdonságai &
\end{tabular}

\subsubsection{Plasticizer}

A plasticizer with a specific gravity of $1.04 \pm 0.01 \mathrm{~g} / \mathrm{cm}^{3}$, solid content of $35 \%$ and $\mathrm{pH}$ of 7.9 , was used to ensure the suitable workability of mortar mixtures.

\subsection{Mix proportions and mixing procedure}

To assess the effect of EPS on the physical, mechanical and thermal properties of lightweight mortar, seven mixtures were prepared. In order to determine the quantity required for each ingredient of lightweight mortar, the general method is used according to the standard EN 196-1 [18]. Cement/sand (S/C) ratio is maintained constant $(1 / 3)$. Sand was substituted by EPS with percentages of 0, 5, 10, 15, 20, 25 and 100\%. In order to reach suitable workability, varying amounts of plasticizer (PL) and water/cement (W/C) ratio were used. The mixture proportions of all lightweight mortar mixes are given in Table 3.

\begin{tabular}{|c|c|c|c|c|c|c|c|c|}
\hline \multicolumn{2}{|c|}{ Mixtures } & 1 & 2 & 3 & 4 & 5 & 6 & 7 \\
\hline \multicolumn{2}{|c|}{$\begin{array}{l}\text { Cement } \\
\left(\mathrm{kg} / \mathrm{m}^{3}\right)\end{array}$} & 450 & 450 & 450 & 450 & 450 & 450 & 450 \\
\hline \multicolumn{2}{|c|}{$\begin{array}{l}\text { Sand } \\
\left(\mathrm{kg} / \mathrm{m}^{3}\right)\end{array}$} & 1302.50 & 1237.38 & 1107.13 & 976.88 & 651.25 & 325.63 & 0.00 \\
\hline \multicolumn{2}{|c|}{ EPS (\%) } & 0 & 5 & 15 & 25 & 50 & 75 & 100 \\
\hline \multicolumn{2}{|c|}{$\begin{array}{l}\text { EPS } \\
\left(\mathrm{kg} / \mathrm{m}^{3}\right)\end{array}$} & 0.00 & 0.82 & 2.45 & 4.09 & 8.17 & 12.26 & 16.34 \\
\hline \multirow{2}{*}{$w / C$} & * & 0.55 & 0.5 & 0.48 & 0.44 & 0.38 & 0.33 & 0.27 \\
\hline & $* *$ & 0.5 & 0.47 & 0.43 & 0.4 & 0.34 & 0.29 & 0.26 \\
\hline \multirow{2}{*}{$\begin{array}{l}\text { PL } \\
\text { (\%) }\end{array}$} & * & 0.5 & 0.5 & 0.5 & 0.5 & 0.5 & 0.5 & 0.5 \\
\hline & $* *$ & 1 & 1 & 1 & 1 & 1 & 1 & 1 \\
\hline
\end{tabular}

Table 3 Mix proportions of different EPS mortars 3. táblázat Habarcs keverékek összetétele

The mixing procedure for making control mortar mixtures takes three steps. Firstly, the cement and sand were mixed for $1 \mathrm{~min}$, and then $80 \%$ of the mixing water was added and mixed for $1 \mathrm{~min}$. The remaining 20\% of water containing the $\mathrm{PL}$ was then added and mixed for $1 \mathrm{~min}$. Finally, the procedure continued for another $2 \mathrm{~min}$. For the mixture containing EPS, with an additional mixing time of $2 \mathrm{~min}$. 


\subsection{Testing}

- The workability was measured according to the standard NF P 15-437 [19].

- The air content in the mortars was measured by aerometer according to the standard NF P 18-353 [20].

- The dry density of the composites was measured according to the standard NF P18-435[21].

- The flexural strength and compressive strength are measured 28 days according to ASTM C348 [22] and ASTM C349 [23] standards, respectively.

- The measurements of the thermal properties were carried out according to the standard ISO 8497-1 [24].

- The porosity accessible to water was measured according to standard NFEN18-459 [25].

- The dynamic elastic modulus of composites was determined at 28 days, using the ultrasonic pulse velocity (UPV) test according the standard ASTM C597-97 [26].

- To understand the developing of microstructure of hardened mixtures, a scanning electron microscopy analysis (SEM) was performed.

\section{Results and Discussion}

\subsection{Fresh properties}

\subsubsection{Workability}

Table 3 shows that the values of the W/C ratio decrease with the increase in the dosage of EPS beads, due to the polystyrene properties, it is a material that does not absorb water through a closed cellular structure [27]. These results are confirmed by the studies carried out by Bengin et al [28]. Kim et al [29] investigated the effect of polystyrene on the workability of lightweight mortars; and found that the increase in polystyrene content causes an increase in workability. Madandoust et al [30] showed that the use of EPS decreased the demand for high range water reducer, while higher slump flow was achieved. The plasticizer was added to the mixture in order to improve the consistency class of mortar with the fluidity time less than 10 s. The optimization of the percentage of PL consists in developing the best characteristics of mortar at the fresh state to ensure better performance at the hardened state. In this study, two percentages of PL were used; $0.5 \%$ and $1 \%$ by weight of cement.

Fig. 2 shows the variation of the workability of mortars with different percentages of EPS. As shown in Fig. 2, the flow time for all mixes was between 7 and $11 \mathrm{~s}$, which indicates good consistency and compliance with flow time limitation so that requirement is less than $10 \mathrm{~s}$ in order to have a similar fluidity. It was noted that, mortars with $1 \%$ of PL have a high fluidity compared to those with $0.5 \%$ of PL [31]. For visual control, the setting is easy without any tendency to segregation or bleeding for the high percentages of EPS beads. This is due to the increase in the percentage of EPS, which is characterized by a hydrophobic behavior.

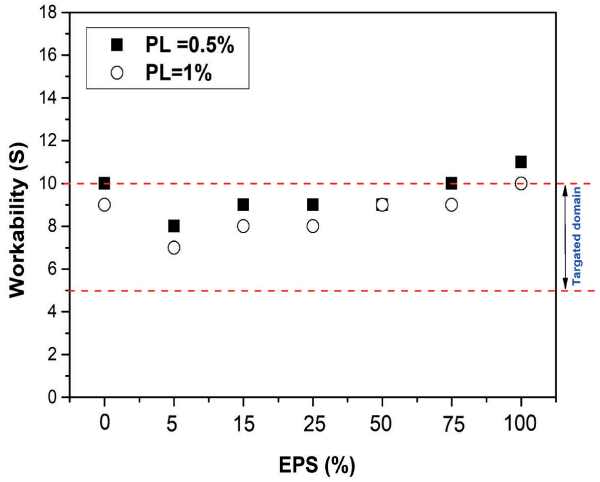

Fig. 2 Workability of mortars made with different EPS contents

2. ábra Különbözö EPS tartalommal készített habarcsok bedolgozhatósága

\subsubsection{Air content}

The variation of the air content of the composite as a function of the EPS content, is illustrated in Fig. 3. According to this figure, the air content of mortars with EPS is more important than that of reference mortar with $0 \%$ of EPS. Up to $15 \%$ of EPS substitution, the air content increases with increasing the EPS content from $6.2 \%$ for mortar with $0 \%$ of EPS to $9.1 \%$ for mortar with $100 \%$ of EPS. However, the incorporation of $5 \%$ of EPS decreases the air content in the mixture by $20 \%$ compared to the control mortar. The decrease is due to the increase in compactness of the composite, it can be confirmed by the results of the workability test of this mixture. These results seem to be similar for the both plasticizer percentages used. The increase in the air content is explained by the increase in porosity, which can be attributed to the morphology of EPS, which is characterized by a hydrophobic nature. This explains that the EPS composite is less compact, and therefore it is more porous compared to the control mortar and that EPS balls can trap air, thus significantly increasing the air volume in composites. Increasing the air content in fresh mixture is practically identical with increasing the porosity of the composite at hardened state to the detriment of mechanical strength and the durability of the composite in general.

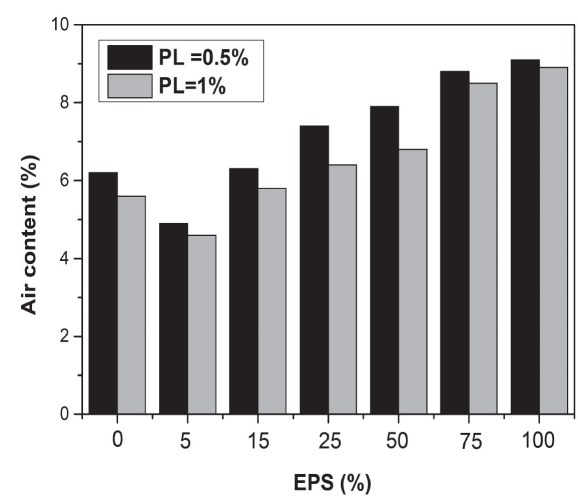

Fig. 3 Air content of mortars made with different EPS contents

3. ábra Különbözö EPS tartalommal készitett habarcsok levegötartalma

\subsection{Hardened properties}

\subsubsection{Density}

The evolution of the density of the composite with various EPS content is given in Fig. 4; the figure shows that the density 
varies from $2227.5 \mathrm{~kg} / \mathrm{m}^{3}$ to $944.01 \mathrm{~kg} / \mathrm{m}^{3}$ for mixtures with $1 \%$ of PL. For the control mortar, the density was $2204.98 \mathrm{~kg} / \mathrm{m}^{3}$, and it decreased to $962.66 \mathrm{~kg} / \mathrm{m}^{3}$, when incorporating $100 \%$ of EPS and $0.5 \%$ of PL in the mixture. This low density can also facilitate the implementation of concrete in construction sites [32]. In addition, the decrease in the density is related to the increase of the air content in the matrix, which increases with the increase of EPS content [33-35]. Therefore, the substitution of sand by EPS has a negative effect on the density of the all mixtures, whereas the increase in the percentage of plasticizer causes an increase in density. These results were expected because the density of EPS is lower than that of the control mixture.

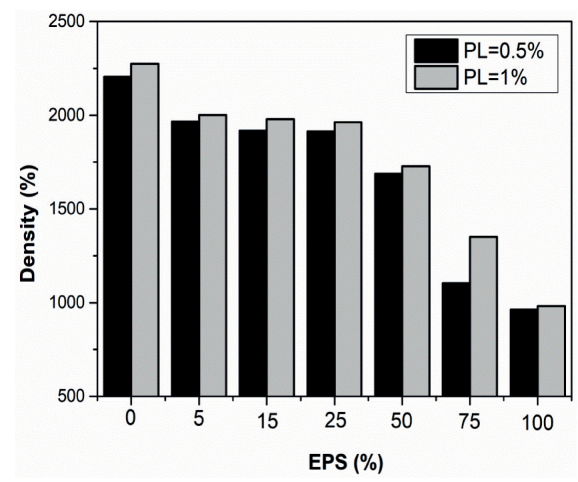

Fig. 4 Density of mortars made with different EPS contents 4. ábra Különbözö EPS tartalommal készitett habarcsok sürüsége

\subsubsection{Compressive Strength}

The variation of the compressive strength of the mixtures with different substitution rates of EPS is shown in Fig. 5. From the figure, it can be seen that the compressive strength considerably decreases with the increase in the content of EPS, but it remains acceptable, even for mortars with a content of $100 \%$ of EPS as used in semi-solid insulators manufacture.

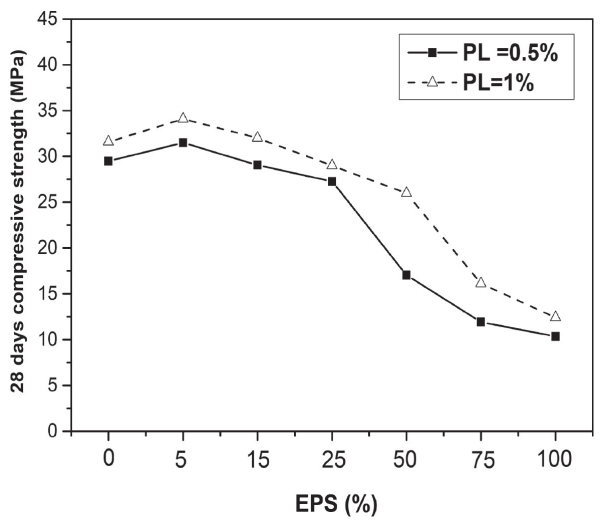

Fig. 5 Compressive strength at 28 days of mortars made with different EPS contents 5. ábra Különbözö EPS tartalommal készített habarcsok 28 napos nyomószilárdsága

The compressive strength of mortar with $100 \%$ of EPS decreases from 31.58 $\mathrm{MPa}$ to $12.4 \mathrm{MPa}$ and from 29.47 $\mathrm{MPa}$ to $10.34 \mathrm{MPa}$, compared to the control mixture, when using $1 \%$ and $0.5 \%$ of PL respectively. This reduction in strength is attributed to the stiffness of polystyrene, which is much lower compared to that of natural aggregates on one hand. On the other hand, the porosity percentage of the produced composites increases with the increase of the percentage of the EPS balls $[36,37]$. However, a slight increase in the compressive strength of mortars is noted with the incorporation of $5 \%$ of EPS; this is due to the decrease in the $\mathrm{W} / \mathrm{C}$ ratio as well as to the small percentage of the porosity of mixture.

\subsubsection{Flexural tensile strength}

Fig. 6 shows the 28 days flexural tensile strength of mortars made with different percentages of EPS. It is found that, the flexural strength of mortar decreases when adding EPS. for example, the flexural strength decreases from 4.51 to $2.79 \mathrm{MPa}$ for mortars with EPS content of $0 \%$ and $100 \%$ respectively, which represents a reduction rate of about $40 \%$, whatever the percentage of PL used. This decrease in the flexural strength is probably due to the microstructure of mortar, which is characterized by high porosity and low adhesion between the EPS beads and the cement paste $[38,39]$. These results are similar to those previously obtained by some authors on lightweight aggregate-based mortars [36, 37]

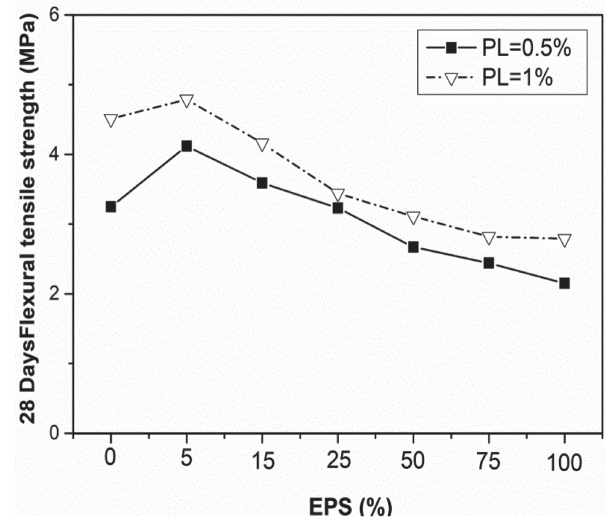

Fig. 6 Flexural tensile strength at 28 days of mortars made with different EPS contents

6. ábra Különbözö EPS tartalommal készitett habarcsok 28 napos hajlitóhúzószilárdsága

\subsubsection{Dynamic modulus of elasticity}

Fig. 7 shows the evolution of the dynamic modulus of elasticity at 28 days of the composites as a function of the EPS content. The figure illustrates that the modulus of elasticity of mortar varies in the same way as the flexural tensile strength and decreases with the increase of EPS content. The reduction rate of dynamic modulus of elasticity is about $85 \%$ when incorporating $100 \%$ of EPS in mixture compared to that with $0 \%$ of EPS, whatever the percentage of PL used. The weak bond between the matrix and the EPS balls may have contributed to this reduction. In addition, the presence of air bubbles in the matrix may accentuated this reduction. The waves must pass through these air bubbles in order to be propagated in the cement paste [40]. This highlights the capacity to mitigate the ultrasonic waves as well as the damping of vibrations, which indicates the good sound insulation behavior. 


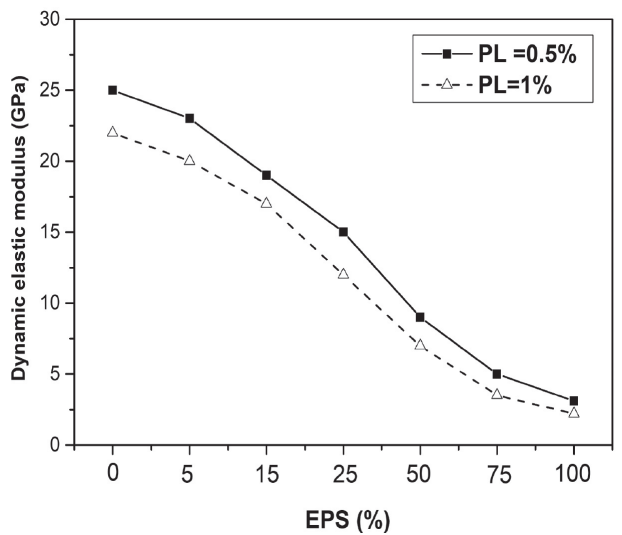

Fig. 7 Dynamic modulus of elasticity of mortars made with different EPS contents

7. ábra Különbözö EPS tartalommal készített habarcsok dinamikus rugalmassági modulusa

\subsubsection{Porosity}

Fig. 8 shows the porosity accessible to water of different mortar mixtures as function of EPS aggregates percentages. From this figure, it can be noticed that, the two series of composites have the same behavior of the evolution of porosity versus the incorporated volume of EPS; the porosity of mixtures increases as the EPS content increases. For example, for mixtures with $0.5 \%$ of PL, the porosity increases from $8 \%$ to $27 \%$ when the EP S content increases from $0 \%$ to $100 \%$. For composites with $1 \%$ of PL, the porosity varies from $7 \%$ to $24 \%$ when the EPS content varies from $0 \%$ to $100 \%$. This increase is due to the low adhesion between the cement matrix and the EPS beads, which are characterized by hydrophobic nature in which the alveolus-shape cells are closed and remove of a part of the matrix resulting in a more complex porous structure [12]. These results are similar to those found by other researchers [41, 42]. G. Babu and S. Babu [43] studied the effect of EPS content on the porosity of concrete. The results showed an increase in porosity with the inclusion of high EPS content compared to control mixtures.

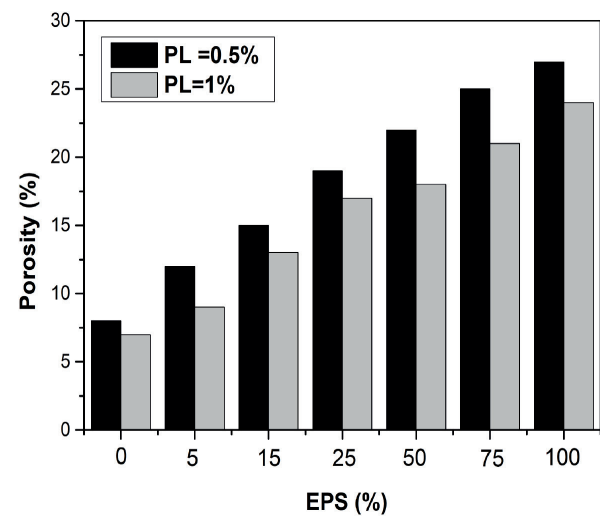

Fig. 8 Porosity of mortars made with different EPS contents

8. ábra Különböző EPS tartalommal készitett habarcsok porozitása

\subsection{Thermal properties}

The results of the thermal properties: conductivity, diffusivity, effusivity and resistance of composites with different EPS proportions are shown in Figs. 9, 10, 11 and 12 respectively.

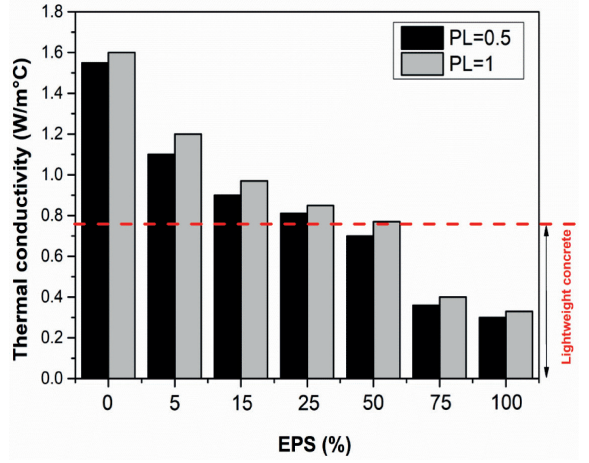

Fig. 9 Thermal conductivity of mortars made with different EPS contents 9. ábra Különböző EPS tartalommal készitett habarcsok hövezető képessége

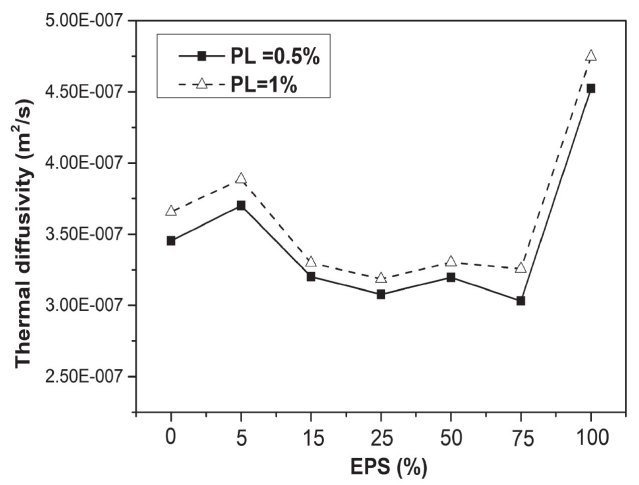

Fig. 10 Thermal diffusivity of mortars made with different EPS contents 10. ábra Különbözö EPS tartalommal készített habarcsok höterjedési képessége

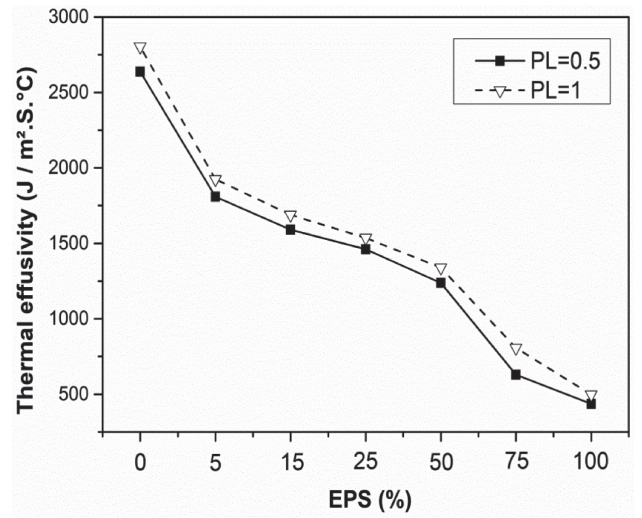

Fig. 11 Thermal effusivity of mortars made with different EPS contents 11. ábra Különbözö EPS tartalommal készített habarcsok hökibocsátó képessége

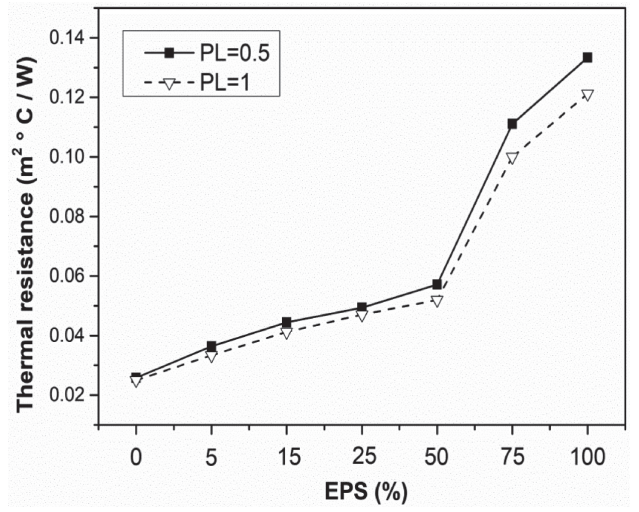

Fig. 12 Thermal resistance of mortars made with different EPS contents 12. ábra Különbözö EPS tartalommal készitett habarcsok termikus ellenállása 
Fig. 9 shows the thermal conductivity variation of composites with different EPS contents. It can noted that the thermal conductivity of mortar decreases with the increase in the percentage of EPS beads compared to that of the composite control. This corresponds to a reduction of about $80 \%$ for the composite with $100 \%$ of EPS compared to the composite without EPS. This reduction in thermal conductivity is due to the morphology of EPS, which represents an amorphous structure and its low thermal conductivity is $0.4 \mathrm{~W} / \mathrm{m}^{\circ} \mathrm{C}$ compared to natural aggregates that represent a crystalline structure and a thermal conductivity more than $1.5 \mathrm{~W} / \mathrm{m}^{\circ} \mathrm{C}$ [44]. The RILEM recommendations reported that all mixtures studied, except the control, are classified in the "class II" of lightweight concrete of construction and insulation, based on their range of thermal conductivity less than $0.75 \mathrm{Wm}^{-1} \mathrm{k}^{-1}$ [45]. Laoubi et al [46] found that the conductivity of the lightweight plaster decreased with the increase in the quantity of EPS, due to the insulating effect of the EPS.

Figs. 10 and 11 show the results of the thermal diffusivity and the thermal effusivity of the different composites. It is observed that, the diffusivity and effusivity values are in the range between $(3.454-4.743) \times 10^{-7} \mathrm{~m} / \mathrm{s}^{2}$ and $(2637.244-435.592)$ $\mathrm{J} / \mathrm{m}^{2} \mathrm{~s}^{\circ} \mathrm{C}$ respectively. From this result, it can be concluded that, the incorporation of EPS beads decreases these parameters, due to the insulating effect of the EPS beads, which makes the produced composite more efficient thermally.

The results of thermal resistance of mortars with different percentages of EPS is shown in Fig. 12. The figure reveals the positive effect of adding EPS beads in improving the thermal resistance of composites. For control mortar, thermal resistance is $0.026 \mathrm{~m}^{2 \circ} \mathrm{C} / \mathrm{W}$ which increases to $0.133 \mathrm{~m}^{20} \mathrm{C} / \mathrm{W}$ for mortar prepared with $100 \%$ of EPS and $0.5 \%$ of PL. According to the standard NFP 75-101 [47], if the thermal resistance of product is at least equal to $0.50 \mathrm{~m}^{2 \circ} \mathrm{C} / \mathrm{W}$, it can be classified as a good thermal insulator in the building. This classification shows that all mortars were belonged to the NFP 75-101 limitation standard.

\subsection{Microstructure analysis using SEM}

The analysis of the specimens' morphology was carried out using a scanning electron microscopy (SEM) in order to highlight the interaction between cement-aggregates zones and the eventual changes of the microstructure of the composites within the incorporation different EPS contents. Fig. 13 shows some SEM images for samples of EPS composite mortars after 28 days of maturity.

Fig. $13 a$ shows that the specimen has an alveolar structure of the EPS beads, which explains the lightness of the produced composites. Figs. 13 b, $c$ show a poor adhesion of interfacial transition zone (ITZ) between cement-aggregates, which can significantly reduce the strength. This may be because that EPS beads have surface electrostatic charges that move the paste on EPS ball-paste contact area and known as the aggregate paste interaction.

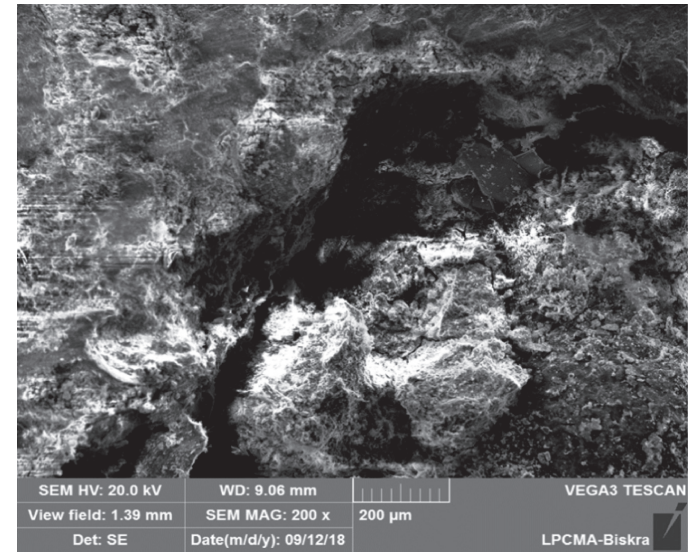

Fig. 13.a SEM appearance of the porous EPS beads structure

13a. ábra A porózus EPS szerkezetének felépitése pásztázó elektronmikroszkópos felvételen

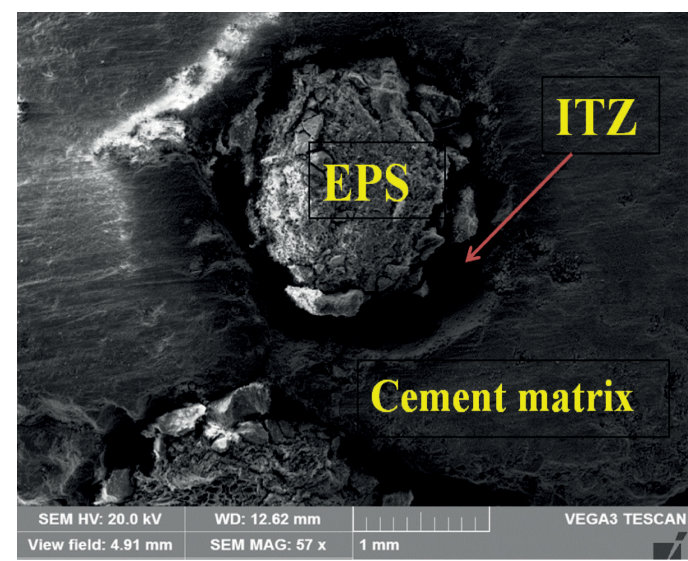

Fig. 13.b Interfacial transition zone between EPS beads and the cement matrix 13b. ábra Felületi átmeneti zóna az EPS gyöngyök és a cementmátrix között

Fig. $13 d$ reveals that, the adhesion between EPS and the cement matrix is weak; this is because the EPS beads form agglomerations. The analysis of the interface "cementaggregate" showed the bad adhesion between the EPS and the cement matrix. Indeed, some gaps have been observed between these two components as shown in Fig. $13 \mathrm{e}$. The incorporation of EPS beads seems affect the total pore volume in the mixture, which results in high porosity and producing a more complex pore network in the composite.

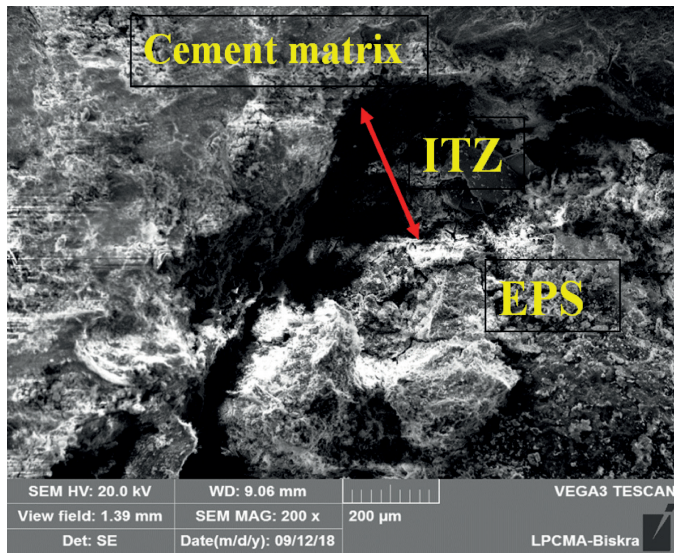

Fig. 13.c Interfacial transition zone EPS beads and the cement matrix 13 c. ábra Felületi átmeneti zóna az EPS gyöngyök és a cementmátrix között 


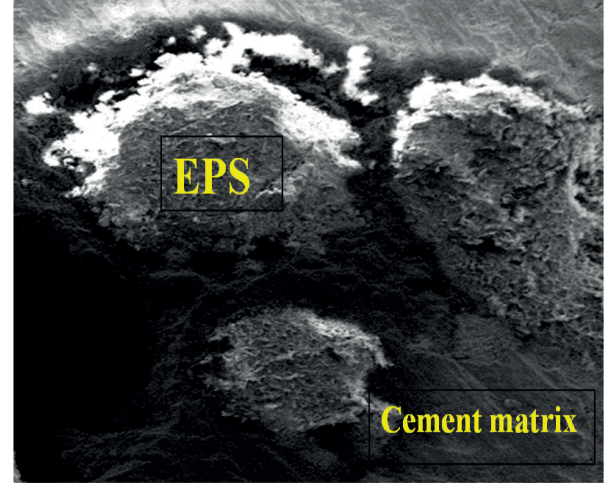

Fig. 13.d SEM observation of the grouping of EPS beads in the mass of the cement matrix 13d. ábra Pásztázó elektronmikroszkópos felvételen az EPS gyöngyök csoportosulása a cement mátrixban

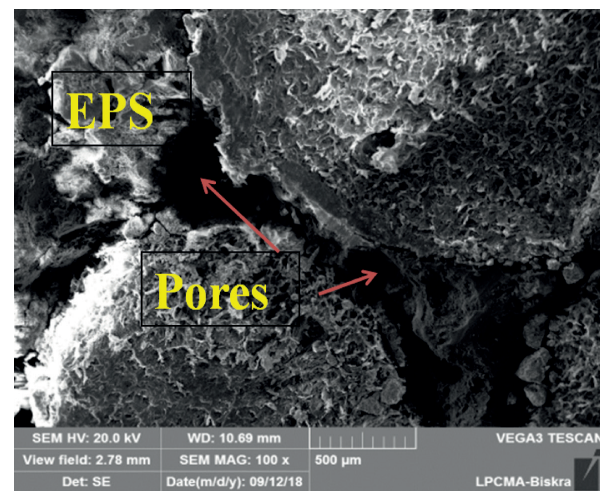

Fig. 13.e Interfacial transition zone EPS beads and the cement matrix 13.e ábra Felületi átmeneti zóna az EPS gyöngyök és a cementmátrix között

\subsection{Relationships between the properties of ESP composites}

The relationship between the compressive strength and density is illustrated in Fig. 14. The figure indicates that the compressive strength of composite decreases proportionally with density; the decrease in compressive strength of the EPS composite is associated with a decrease in density with a good coefficient of correlation $\left(\mathrm{R}^{2}>0.8\right)$. This decrease was about $60 \%$ for both strength density. In this aspect, Sayadi et al [9] have found that the evolution of the compressive strength of concretes and mortars decreases with the increase of polystyrene substitution. An improvement of the resistance is obtained for the substitution of 5\% in EPS; it is related to the decrease of the percentage of the density of this composite.

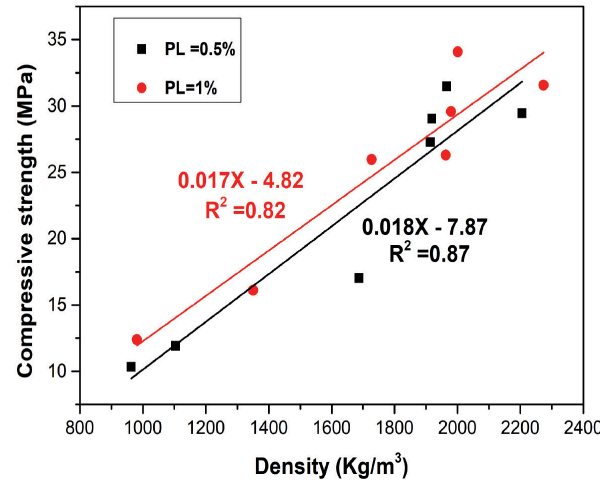

Fig. 14 Correlation between compressive strength and density of EPS composites 14. ábra EPS kompozitok nyomószilárdságának és sürüségének összefüggése
Fig. 15 shows the correlation established between the compressive strength and thermal conductivity. According to this figure, it is noted that, a decrease in the compressive strengths is associated with a decrease in thermal conductivity. A good non-linear correlation for all mixtures $\left(\mathrm{R}^{2}>0.9\right)$ is found between the two properties.

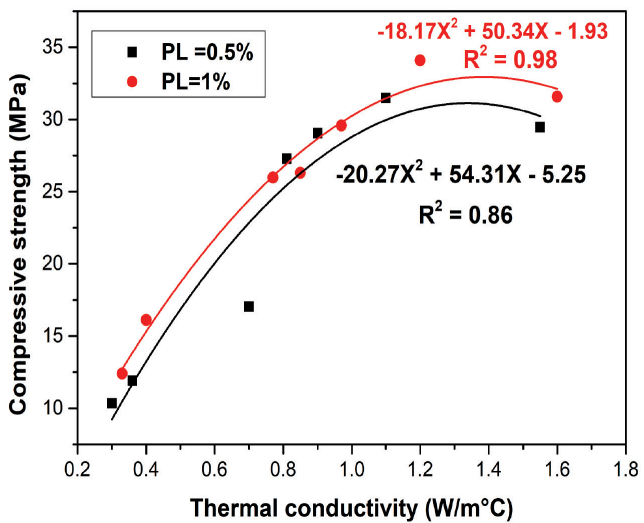

Fig. 15 Correlation between compressive strength and thermal conductivity of EPS composites

15. ábra EPS kompozitok nyomószilárdságának és hővezető képességének összefüggése

Figs. 16 and 17 illustrate the relationship between the thermal conductivity, density and porosity for all mixtures, respectively. It can be seen that, a good linear correlation is therefore observed between the parameters studied with high coefficients of correlation.

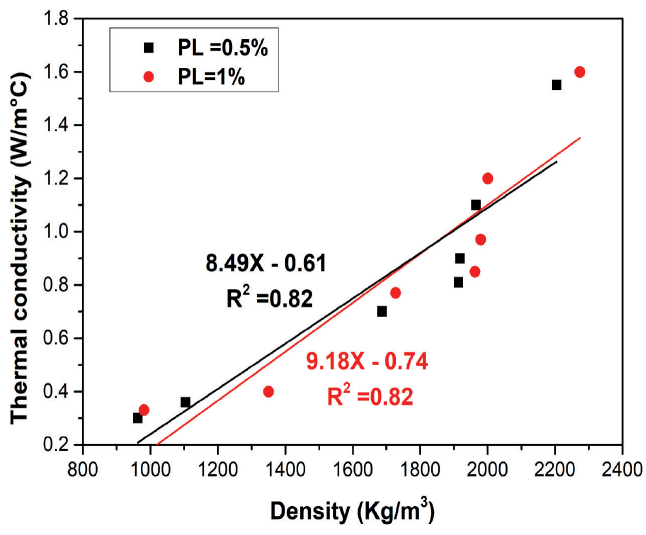

Fig. 16 Correlation between thermal conductivity and density of EPS composites 16. ábra EPS kompozitok hövezető képességének és sürüségének összefüggése

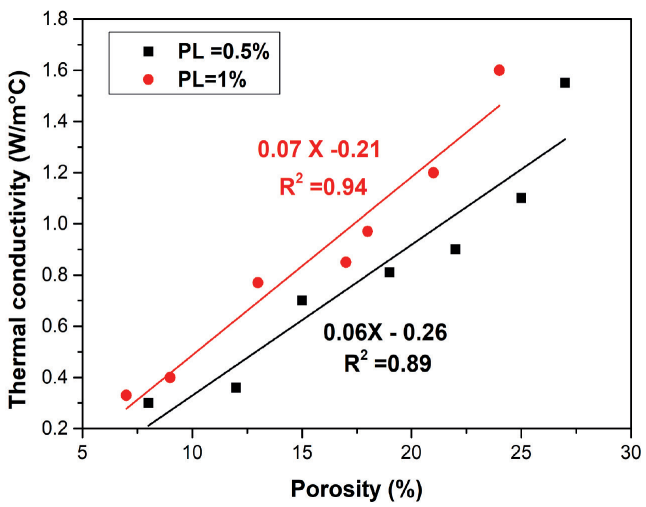

Fig. 17 Correlation between thermal conductivity and porosity of EPS composites 17. ábra EPS kompozitok hövezető képességének és porozitásának összefüggése 


\section{Conclusions}

The present experimental study investigated the physicmechanical and thermal performances of dune sand mortars containing EPS as aggregate, the following conclusions can be drawn:

- The incorporation of EPS beads as aggregate improved the workability of mortar.

- An increase in the percentage of EPS beads is accompanied by the increase of the air content of the composites, which increases the voids inside the matrix and consequently increases its porosity.

- The compressive strength and flexural tensile strength decreased as the quantity of EPS beads increased, except the mixture with 5\% of EPS that gives the best mechanical performance compared to other mixtures.

- The modulus of elasticity of the composites lightened by EPS relatively decreases according to the increase in the percentage of EPS, which means greater deformability in the reference matrices and therefore less risk cracking.

- The increase of EPS percentages of substitution up to $50 \%$ decreased significantly the density of the composites.

- The microstructure analysis showed that the use of EPS in mixtures caused an increase in porosity as well as a weak adhesion zone between cement and aggregate.

- The thermal properties of all mixtures are significantly decreased by the addition of the EPS; it was possible to obtain a thermal conductivity equal to $0.30 \mathrm{Wm}^{-10} \mathrm{C}^{-1}$ for when $100 \%$ of EPS is used. It should be noted that the obtained values of the thermal conductivity meet the RILEM recommendations, which suggest a coefficient of thermal conductivity less than $0.75 \mathrm{Wm}^{-10} \mathrm{C}^{-1}$ for lightweight concrete construction and insulation applications.

- Finally, the EPS composites could be the subject of several applications, and can be used to reduce the heat transfer and thus to save energy.

\section{Acknowledgments}

The authors are very grateful to the head of the department of civil engineering and staff of the civil engineering laboratory of University of Medea, for their assistance in carrying out this experimental work. The staff of the Laboratory of the National Center for Integrated Research and Studies in Building (CNERIB) is warmly thanked for the thermal properties measurements.

\section{References}

[1] Ouldkhaoua, Y., Benabed, B., Abousnina, R., Kadri, E., Khatib, J. (2020) Effect of using metakaolin as supplementary cementitious material and recycled CRT funnel glass as fine aggregate on the durability of green selfcompacting concrete. Construction and Building Materials. 235, 117802. https://doi.org/10.1016/j.conbuildmat.2019.117802

[2] Thienel, K.C., Haller, T., Beuntner, N. (2020) Lightweight concrete-from basics to innovations. Materials. 13, 1120. https://doi.org/10.3390/ma13051120
[3] Yang, K.H., Mun, J.H., Kim, S.J., Lee, H.J. (2020) Flexural behavior of twospan lightweight aggregate concrete T-beams. ACI Structural Journal. 117, pp. 267-276. https://doi.org/10.14359/51721368

[4] Vakhshouri, B., Nejadi, S. (2018) Review on the mixture design and mechanical properties of the lightweight concrete containing expanded polystyrene beads. Australian Journal of Structural Engineering. 19, pp. 1-23. https://doi.org/10.1080/13287982.2017.1353330

[5] Fenyvesi, O., Jankus, B., (2015) Opportunities in recycling AAC waste as aggregate for lightweight concrete. Építőanyag - Journal of Silicate Based and Composite Materials. 67, pp. 66-70.

http://dx.doi.org/10.14382/epitoanyag-jsbcm.2015.11

[6] Ouldkhaoua, Y., Benabed, B., Abousnina, R., Kadri, E. (2019) Rheological properties of blended metakaolin self-compacting concrete containing recycled CRT funnel glass aggregate, Epitoanyag-Journal of Silicate Based \& Composite Materials. 71, pp. 154-161.

https://doi.org/10.14382/epitoanyag-jsbcm.2019.27

[7] Herki, B., Khatib, J., Negim, E. (2013) Lightweight concrete made from waste polystyrene and fly ash. World Applied Sciences Journal. 21, pp. 1356-1360. https://doi.org/10.5829/idosi.wasj.2013.21.9.20213

[8] Ferrándiz-Mas, V., Bond, T., García-Alcocel, E., Cheeseman, C.R. (2014) Lightweight mortars containing expanded polystyrene and paper sludge ash. Construction and Building Materials. 61, pp. 285-292. https://doi.org/10.1016/j.conbuildmat.2014.03.028

[9] Sayadi, A.A., Tapia, I.V., Neitzert, T.R., Clifton, G.C. (2016) Effects of expanded polystyrene (EPS) particles on fire resistance, thermal conductivity and compressive strength of foamed concrete. Construction and building materials. 112, pp. 716-724. https://doi.org/10.1016/j.conbuildmat.2016.02.218

[10] Ali, M., Maslehuddin, M., Shameem, M., Barry, M. (2018) Thermalresistant lightweight concrete with polyethylene beads as coarse aggregates. Construction and Building Materials. 164, pp. 739-749. https://doi.org/10.1016/j.conbuildmat.2018.01.012

[11] Benabed, B. (2018) Effect of combined use of crushed sand and Algerian desert dune sand on fresh properties and strength of self-compacting concrete. Epitoanyag-Journal of Silicate Based \& Composite Materials. 70, pp. 155-167. https://doi.org/10.14382/epitoanyag-jsbcm.2018.29

[12] Laoubi, H., Djoudi, A., Dheilly, R., Bederina, M., Goullieux, A., Quéneudéc, M. (2019) Durability of a lightweight construction material made with dune sand and expanded polystyrene. Journal of Adhesion Science and Technology. 33, pp. 2157-2179. https://doi.org/10.1080/01694243.2019.1637091

[13] Bédérina, M., Khenfer, M., Dheilly, R., Quéneudec, M. (2005) Reuse of local sand: effect of limestone filler proportion on the rheological and mechanical properties of different sand concretes. Cement and concrete Research. 35, pp. 1172-1179. https://doi.org/10.1016/j.cemconres.2004.07.006

[14] Bouziani, T., Benmounah, A., Bederina, M., Lamara, M. (2011) Effect of marble powder on the properties of self-compacting sand concrete. The Open Construction and Building Technology Journal. 5, pp. 25-29. https://doi.org/10.2174/1874836801105010025

[15] Bouziani, T., Bederina, M., Hadjoudja, M. (2012) Effect of dune sand on the properties of flowing sand-concrete (FSC). International Journal of Concrete Structures and Materials. 6, pp. 59-64. https://doi.org/10.1007/s40069-012-0006-z

[16] Damene, Z., Goual, M., Houessou, J., Dheilly, R., Goullieux, A., Quéneudec, M. (2018) The use of southern Algeria dune sand in cellular lightweight concrete manufacturing: effect of lime and aluminium content on porosity, compressive strength and thermal conductivity of elaborated materials. European Journal of Environmental and Civil Engineering. 22, pp. 1273-1289. https://doi.org/10.1080/19648189.2016.1256233

[17] BS 197-1. (2000) Cement-Part 1: Composition, specifications and conformity criteria for common cements. British Standards Institution.

[18] N. EN, 196-1 (2003) Cements and lime, French Association for Standardization (AFNOR), Paris, 2003.

[19] P. NF, P 15-437 (1987) Hydraulic binders, testing technics. Characterization of cements by fluidity measurement under mortar vibration.

[20] N. EN, 12350-7 (2001) Fresh concrete testing-Part 7.

[21] P 18-435 (2001) Hardened concrete testing - Part 7: Bulk density of concrete. 
[22] C. ASTM, 348 (2000) Standard Test Method for Flexural strength of hydraulic-cement mortars. Annual book of ASTM standards 4, pp. 221-226.

[22] C. ASTM, 349-97 (2002) Standard Test Method for Compressive Strength of Hydraulic-Cement Mortars (Using Portions of Prisms Broken in Flexure), Annual book of ASTM 4.

[23] De Ponte, F., Klarsfeld, S. (2002) Conductivité thermique des isolants. Techniques de l'ingénieur., traité Mesures et Contrôle - Doc. R 2930.

[24] P. NFP 18-459 (2010) Hardened concrete testing, porosity and bulk density.

[25] C. ASTM 597 (2009) Standard test method for pulse velocity through concrete, ASTM International, West Conshohocken, PA.

[26] Tang, W.C., Lo, Y., Nadeem, A. (2008) Mechanical and drying shrinkage properties of structural-graded polystyrene aggregate concrete. Cement and Concrete Composites. 30, pp. 403-409.

https://doi.org/10.1016/j.cemconcomp.2008.01.002

[27] Herki, B. (2017) Absorption characteristics of lightweight concrete containing densified polystyrene. Civil Engineering Journal. 3, pp. 594609. https://doi.org/10.28991/cej-2017-00000115

[28] Kim, H.K., Jeon, J.H., Lee, H.K. (2012) Workability, and mechanical, acoustic and thermal properties of lightweight aggregate concrete with a high volume of entrained air. Construction and Building Materials. 29, pp. 193-200. https://doi.org/10.1016/j.conbuildmat.2011.08.067

[29] Madandoust, R., Ranjbar, M.M., Mousavi, S.Y. (2011) fresh properties of self-compacted lightweight concrete containing expanded polystyrene. Construction and Building Materials. 25, pp. 3721-3731. https://doi.org/10.1016/j.conbuildmat.2011.04.018

[30] Kan, A., Demirboğa, R. (2007) Effect of cement and EPS beads ratios on compressive strength and density of lightweight concrete. Indian Journal of Engineering and Materials Sciences. 14, pp. 158-162

[31] Tasdemir, C., Sengul, O., Tasdemir, M.A. (2017) A comparative study on the thermal conductivities and mechanical properties of lightweight concretes. Energy and Buildings. 151, pp. 469-475. https://doi.org/10.1016/j.enbuild.2017.07.013

[32] Rahmani, E., Dehestani, M., Beygi, M.H.A., Allahyari, H., Nikbin, I.M. (2013) On the mechanical properties of concrete containing waste PET particles. Construction and Building Materials. 47, pp. 1302-1308. https://doi.org/10.1016/j.conbuildmat.2013.06.041

[33] Saikia, N., De Brito, J. (2014) Mechanical properties and abrasion behaviour of concrete containing shredded PET bottle waste as a partial substitution of natural aggregate. Construction and building materials. 52, pp. 236-244. https://doi.org/10.1016/j.conbuildmat.2013.11.049

[34] Allahverdi, A., Azimi, S.A., Alibabaie, M. (2018) Development of multistrength grade green lightweight reactive powder concrete using expanded polystyrene beads. Construction and Building Materials. 172, pp. 457-467. https://doi.org/10.1016/j.conbuildmat.2018.03.260

[35] Nikbin, I.M., Golshekan, M. (2018) The effect of expanded polystyrene synthetic particles on the fracture parameters, brittleness and mechanical properties of concrete. Theoretical and Applied Fracture Mechanics. 94, pp. 160-172. https://doi.org/10.1016/j.tafmec.2018.02.002
[36] Kuhail, Z., Shihada, S. (2003) Mechanical properties of polystyrenelightweight concrete. Journal of Islamic University of Gaza. 11, pp. 93-114

[37] Sohel, K.M.A., Al-Jabri, K., Zhang, M.H., Richard Liew, J.Y. (2018) Flexural fatigue behavior of ultra-lightweight cement composite and high strength lightweight aggregate concrete. Construction and Building Materials. 173, pp. 90-100. https://doi.org/10.1016/j.conbuildmat.2018.03.276

[38] Aboul-Nour, L.A., Zaghlal, A., Yahia, M., Malek, K.A. (2020) Flexural behavior of structural lightweight concrete beam. International Journal of Civil Engineering and Technology. 11, pp.329-339

[39] Assaad, J.J., El Mir, A. (2020) Durability of polymer-modified lightweight flowable concrete made using expanded polystyrene. Construction and Building Materials. 249, 118764.

https://doi.org/10.1016/j.conbuildmat.2020.118764

[40] Dixit, A., Dai Pang, S., Kang, S.H., Moon, J. (2019) Lightweight structural cement composites with expanded polystyrene (EPS) for enhanced thermal insulation. Cement and Concrete Composites. 102, pp. 185-197. https://doi.org/10.1016/j.cemconcomp.2019.04.023

[41] Koksal, F., Mutluay, E., Gencel, O. (2020) Characteristics of isolation mortars produced with expanded vermiculite and waste expanded polystyrene. Construction and Building Materials. 236, 2020, 117789. https://doi.org/10.1016/j.conbuildmat.2019.117789

[42] Babu, K.G., Babu, D.S. (2003) Behaviour of lightweight expanded polystyrene concrete containing silica fume. Cement and Concrete Research. 33, pp. 755-762. https://doi.org/10.1016/S0008-8846(02)01055-4

[43] Remesar, J.C., Simon, F., Vera, S., Lopez, M. (2020) Improved balance between compressive strength and thermal conductivity of insulating and structural lightweight concretes for low-rise construction. Construction and Building Materials. 247, 118448. https://doi.org/10.1016/j.conbuildmat.2020.118448

[44] RILEM. (1970) Commission des bétons légers. Terminologie et définition. Matériaux et construction Terminology and definition. Materials and Construction. pp. 60-69.

[45] Laoubi, H., Bederina, M., Djoudi, A., Goullieux, A., Dheilly, R.M., Queneudec, M. (2018) Study of a new plaster composite based on dune sand and expanded polystyrene as aggregates. The Open Civil Engineering Journal. 12, pp. 4016412. https://doi.org/10.2174/1874149501812010401

[46] NF P 75 101. Thermal Insulators for Building. October 1983.

Ref.:

Herihiri, Ouided - Guettala, Abdelhamid - Benabed, Benchaa: An investigation on the physical, mechanical and thermal properties of dune sand mortars lightened by expanded polystyrene beads (EPS) Építöanyag - Journal of Silicate Based and Composite Materials, Vol. 73, No. 1 (2021), 28-36. p. https://doi.org/10.14382/epitoanyag-jsbcm.2021.6

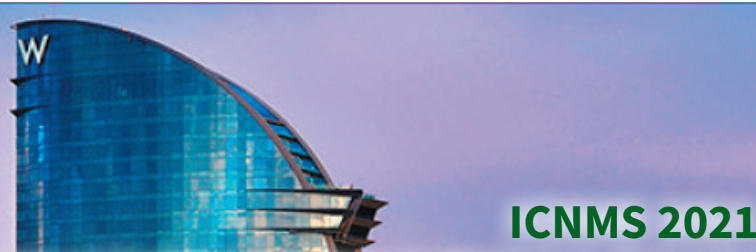

$15^{\text {th }}$ International Conference on Nanotechnology in Materials Sciences, May 24-25, 2021 in Barcelona, Spain

CNMS 2021: 15. International Conference on Nanotechnology in Materials Sciences aims to bring together leading academic scientists, researchers and research scholars to exchange and share their experiences and research results on all aspects of Nanotechnology in Materials Sciences. It also provides a premier interdisciplinary platform for researchers, practitioners and educators to present and discuss the most recent innovations, trends, and concerns as well as practical challenges encountered and solutions adopted in the fields of Nanotechnology in Materials Sciences

waset.org/nanotechnology-in-materials-sciences-conference-in-may-2021-in-barcelona 